\title{
Strategies to Circumvent Host Innate Immune Response by Hepatitis C Virus
}

\author{
Tapas Patra ${ }^{1}$, Ratna B. Ray ${ }^{2}$ and Ranjit Ray ${ }^{1,3, *}$ \\ 1 Departments of Internal Medicine, Saint Louis University, St. Louis, MO 63104, USA; \\ tapas.patra@health.slu.edu \\ 2 Departments of Pathology, Saint Louis University, St. Louis, MO 63104, USA; rayrb@slu.edu \\ 3 Molecular Microbiology \& Immunology, Saint Louis University, St. Louis, MO 63104, USA \\ * Correspondence: rayr@slu.edu; Tel.: +1-(314)-977-9034; Fax: +1-(314)-771-3816
}

Received: 4 January 2019; Accepted: 18 March 2019; Published: 22 March 2019

check for updates

\begin{abstract}
Innate immune responses generate interferons, proinflammatory cytokines, complement activation, and natural killer $(\mathrm{NK})$ cell response. Ultimately, this leads to the induction of a robust virus-specific adaptive immunity. Although the host innate immune system senses and responds to eliminate virus infection, hepatitis $\mathrm{C}$ virus (HCV) evades immune attack and establishes persistent infection within the liver. Spontaneous clearance of HCV infection is associated with a prompt induction of innate immunity generated in an infected host. In this review, we have highlighted the current knowledge of our understanding of host-HCV interactions, especially for endogenous interferon production, proinflammatory response, NK cell response, and complement activation, which may impair the generation of a strong adaptive immune response for establishment of chronicity. The information may provide novel strategies in augmenting therapeutic intervention against $\mathrm{HCV}$.
\end{abstract}

Keywords: hepatitis C virus; innate immunity; interferon; cytokine; NK cell; complement

\section{Introduction}

HCV was identified in 1989 as one of the etiological agents of viral hepatitis [1]. HCV is a small enveloped RNA virus belonging to genus Hepacivirus and family Flaviviridae. The positive-sense single-stranded RNA genome of HCV is around $9.6 \mathrm{~kb}$ in size, flanked by UTRs on both ends. The single open reading frame present in this genome encodes for a nonfunctional polyprotein precursor which is cleaved by cellular and viral proteases into three structural and seven nonstructural proteins [2,3]. $\mathrm{HCV}$ is classified into seven genotypes and several subtypes expanding the diversity of the genomic sequence [4]. Approximately 177.5 million people in the world are infected by HCV, and annually, 1.3-3.7 million new cases of HCV infection are estimated [5,6]. HCV is spread parenterally, and its mode of transmission includes blood to blood, mother to baby, sexual, and organ transplantation. The clinical picture of HCV infection is often an acute stage, followed by chronic infection in about $80 \%$ of people initially infected $[7,8]$. The acute stage of infection may show mild flu-like symptoms, but is often asymptomatic. Chronic HCV infection often progresses to cirrhosis and hepatocellular carcinoma (HCC). Current estimates suggest approximately 5\% of chronic HCV-infected patients may develop HCC [9]. HCC is the fifth most common cancer worldwide, and the third most common cause of cancer death [10] and liver transplantation in the United States [11].

An HCV-specific standard therapeutic regimen of pegylated interferon- $\alpha$ and ribavirin was approved by the Food and Drug Administration (FDA) in 1999. However, their use is limited to HCV patients with a single subset of genotype, prolonged treatment period, and severe side effects [12,13]. Recent introduction of direct acting antiviral (DAA) achieved sustained virological response (SVR) in a 
majority of HCV-infected patients [14]. However, transient virus clearance and rapid surge of viral resistance against these compounds may cause additional problems. There is a strong necessity for protective vaccine against all the $\mathrm{HCV}$ genotype variants, and it remains a challenge to control $\mathrm{HCV}$ infection globally [15].

The human immune system has developed two arms—innate and adaptive immunity—to act cooperatively, protecting against infection and limiting the damage caused by invading pathogens. Innate immunity acts immediately following infection, directing production of proinflammatory cytokines and orchestrating adaptive immunity. HCV has evolved mechanisms to evade host innate immune response for viral persistence. The persistence of HCV leads to chronic infection which ultimately advances liver disease [16]. It is important to fully interpret the immunopathogenesis of HCV infection and, eventually, exploit effective strategies to eliminate HCV. In this review, we discuss the evasion mechanisms of innate immune responses by HCV, which will deepen our understanding of the therapeutic intervention strategies used for immunity and liver disease prevention.

\section{Endogenous Interferon Production}

Interferon (IFN) pathways are tightly regulated by the host in a cell-intrinsic manner. Host cells are activated to produce type I IFN and proinflammatory cytokines from recognition of viral components, and upregulate a family of IFN-stimulated genes (ISGs) that exert inhibitory effects on viral replication [17]. HCV develops multiple strategies to escape or overcome the antiviral actions of IFN and make chronic infection in the host [18].

Host cells during acute virus infection respond through pathogen recognition receptors (PRRs) and recognize viral pathogen-associated molecular patterns (PAMPs). The retinoic acid inducible gene-1 (RIG-I)-like receptors (RLRs) are cytoplasmic RNA helicases that function as PRRs for the recognition of HCV RNA following infection. RIG-I has three major domains: the C-terminal repressor domain, central DEAD box helicase domain, and caspase activation and recruitment domain (CARD) at the $\mathrm{N}$-terminal. The most important C-terminal domain of RIG-I selectively binds to the $5^{\prime}$-triphosphate, a distinguishing feature of non-self RNA. The $5^{\prime}$-triphosphate of the polyuridine core of the HCV RNA recognizes RIG-I and promotes conformational changes. This conformational change activates type I and type III IFN production by triggering innate antiviral immunity to HCV infection $[19,20]$. On the other hand, conformational changes in RIG-I cause interaction of mitochondrial-associated endoplasmic reticulum membrane (MAM) with mitochondrial antiviral signaling protein (MAVS). This interaction results in assembly of a signalosome complex that activates effector molecules, including the interferon regulatory transcription factor 3 (IRF3) and NFKB, to drive downstream innate immune signaling [21].

To understand how HCV antagonizes IFN signaling, the involvement of several viral proteins has been studied. HCV E2 and NS5A proteins interact with double-stranded (ds) RNA-activated protein kinase R (PKR) and disrupt PKR functions [22,23]. The HCV Core protein induces suppressor of cytokine signaling 3 (SOCS3) and SOCS1 expression, which blocks STAT1 function [24]. HCV Core and NS5A proteins suppress STAT1 phosphorylation in hepatocytes [25]. However, dephosphorylated STAT1, which accumulates in response to IFNs, maintains or increases the expression of a subset of ISGs independently of tyrosine-phosphorylated STAT1 [26]. We reported that HCV-infected hepatocytes display upregulation of total STAT1 without detectable phosphorylated STAT1, and modestly activate interferon-stimulated response element (ISRE) promoter [27]. In the early phase of $\mathrm{HCV}$ infection, the HCV NS3/4A protein cleaves MAVS and fails to transduce the RIG-I/MDA5 signal for IRF3-IFN- $\beta$ activation [28,29]. Another study showed that interference of mitochondrial fission significantly increases ISRE activities, suggesting that HCV evolved strategies independent of NS3/4A in modulating innate immune responses [30].

$\mathrm{HCV}$ genotype $1 \mathrm{~b}$-infected Japanese patients revealed that sequence variation within $\mathrm{HCV}$ NS5A protein at the interferon sensitivity-determining region (ISDR) could predict IFN treatment outcome [31]. However, this observation remains debatable for lack of sufficient clinical observations. 
The capacity of IFN- $\alpha$ production in HCV-infected patients varies, since both high and low IFN- $\alpha$ levels have been reported [32]. IRF7, one of the key ISGs, plays a major role in IFN- $\alpha$ production. IRF7 undergoes phosphorylation when activated and translocates into the nucleus. IRF7 amplifies the type I interferon response by inducing expression of IFN- $\alpha$, which also acts in both autocrine and paracrine manners through the IFN- $\alpha / \beta$ receptor. IRF-7 remains localized in the cytoplasm of HCV-infected hepatocytes [27]. An upregulation of IFN- $\alpha$ occurs at an early point of $\mathrm{HCV}$ infection in cell culture. The initial burst of IFN expression may be for uncoating the virus genome, RNA replication, and translocation of dephosphorylated STAT1 for ISREs activation. However, this activation is not sufficient to trigger high enough antiviral responses to clear HCV. Due to virus infection, IRF-7 fails to translocate into the nucleus and inhibits IFN- $\alpha$ synthesis. HCV infection also inhibits interferon-stimulated gene factor 3 (ISGF3) complex formations by targeting protein phosphatase 2A (PP2A) [33]. Genome-wide association studies (GWAS) suggested a strong relation of genetic variants near the interleukin 28B (IL-28B or IFN $\lambda 3$ ) with pegylated IFN- $\alpha$ treatment-induced clearance of HCV [34]. Polymorphisms in the IL28B (IFNL3) and/or IFNL4 gene also influence immune responses, the capacity to spontaneously eliminate HCV, and response to IFN therapy [35]. However, the current DAA regimen is interferon free, and does not influence genetic variation of the IFN $\lambda 3$ gene.

Toll-like receptors (TLRs) are germline-encoded molecules and are the key components of the innate immune system which recognize endogenous danger-associated molecular patterns (DAMPs) and exogenous PAMPs. Activation of TLRs may limit replication of infectious agents. The role of TLRs in chronic HCV infection has been reported [36]. In-vitro studies indicated that TLR2, -3, -4, -7, and -8 recognize HCV components as PAMP ligands. HCV Core and NS3 proteins trigger the TLR2 signaling pathway and activate inflammation [37]. On the other hand, both TLR3 and TLR7 play roles in sensing of HCV RNA. TLR3 is expressed in liver cells (hepatocytes and Kupffer cells) from HCV infection. TLR3 signals are transduced through the TLR domain containing adapter-inducing IFN- $\beta$ (TRIF) leading to activation of the transcription factors IRF3 and NFKB for induction of innate immunity $[38,39]$. TLR4, a lipopolysaccharide receptor, plays a critical role in PAMPs and activation of innate and adaptive immune responses. HCV NS5A protein plays a potential role in resistance to IFN- $\alpha$ treatment by transactivating TLR4 promoter in vitro. TLR signaling is mediated by the adaptor protein myeloid differentiation factor 88 (MyD88), which triggers the activation of transcription factors important for proinflammatory cytokines. HCV NS5A also associates with the death domain of MyD88 and inhibits TLR7 signaling in mouse macrophages [40]. Further, HCV sensing by TLR7 occurs in both plasmacytoid dendritic cells (pDCs) and Kupffer cells, leading to production of IFN or activation of inflammasome (a multiprotein complex which plays a role in the innate immune response [41]. TLR7 and TLR8 share a high degree of structural similarity and variations in these genes, and impair immune responses during HCV infection [42,43]. Both activation and suppression of TLRs may be necessary to strengthen the anti-HCV immune response for limiting virus replication. Thus, the status of TLR signaling defines the type and strength of the anti-HCV immune response, and the outcome of infection. HCV interferes with the IFN signaling pathway at many different levels for establishment of persistent infection, and targeting these signaling molecules may provide additional therapeutic modalities.

\section{Induction of Proinflammatory Responses}

Inflammation ensures the repair of damaged tissue and removal of detrimental stimuli by host cells [44]. Immune cells, such as macrophages and dendritic cells (DCs), are not the only ones playing an important role; the nonprofessional cells also contribute to inflammation induced by microbial infection [17]. Interleukin-1 $\beta$ (IL-1 $\beta$ ) and IL-18 have important roles in combating the invading pathogen as part of the innate immune response. IL- $1 \beta$-activating platforms, known as inflammasomes, assemble in response to pathogen-associated danger molecules. The inflammasome comprises a family of cytoplasmic membrane-bound PRRs collectively known as NOD-like receptors (NLRs) to sense viral nucleic acid and/or viral proteins. Once activated, NLRs form a multiprotein 
complex with apoptosis-associated speck-like protein containing a carboxy-terminal CARD (ASC) and caspase- 1 for inflammasome assembly, which in turn activates caspase-1 [45]. The production of IL-1 $\beta$ and IL-18 is a tightly regulated process which requires two distinct signals for activation and release [46]. The first signal leads to NFKB activation and synthesis of pro-IL-1 $\beta$ and pro-IL-18 mRNA in a TLR signal-dependent manner. The second signal involves activation of caspase-1, which cleaves pro-IL-1 $\beta$ and pro-IL-18 into biologically active forms. High plasma IL-18 level was seen in the acute phase of HCV infection [47]. The status of IL-1 $\beta /$ IL-18 in HCV-infected hepatocytes and their induction through cross-talk with macrophages were studied meticulously [48-50].

We and others have reported that HCV induces secretion of IL-1 $\beta /$ IL-18 in the THP- 1 cell line (a macrophage cell-culture model), human PBMC-derived macrophages, and primary human Kupffer cells (liver-resident macrophages). We have shown that the induction of these proinflammatory cytokines occurs via the NFKB signaling pathway, suggesting that $\mathrm{HCV}$ initiates inflammasome signal 1 pathway in macrophages. Subsequent studies demonstrated that HCV p7 RNA is sufficient to induce IL-1 $\beta$ secretion from macrophages and is inhibited by $\mathrm{KCl}$ or ion-channel blocker amantadine [48]. Pretreatment with a potassium-channel inhibitor in $\mathrm{HCV}$-incubated macrophages reduces IL-1 $\beta$ maturation [49]. HCV poly(U/UC) RNA transfected into macrophages also triggers IL- $1 \beta$ mRNA expression and secretion, suggesting that $\mathrm{HCV}$ employs multiple strategies for triggering IL-1 $\beta$ secretion. Induction of IL-1 $\beta /$ IL-18 may have positive or negative influence on hepatic inflammation and disease outcome. Interestingly, our recent study demonstrated that HCV induced IL- $1 \beta$ from macrophages does not induce inflammation or activation in human hepatic stellate cells [51]. HCV does establish chronic infection, suggesting that IL-1 $\beta /$ IL-18 may not have an impact on HCV replication and virus clearance, although we cannot rule out their role in spontaneously cured infection.

During the acute-phase inflammatory response, TNF- $\alpha$, along with other cytokines, is produced to activate endothelial cells and leukocytes. They influence the function of other cells involved in adaptive immune responses. In the liver, macrophages and Kupffer cells are the main sources of TNF- $\alpha$ [52]. The liver comprises mostly hepatocytes ( 60-80\%) which can produce TNF- $\alpha$ during chronic HCV infection $[53,54]$. The TNF- $\alpha$ signal is transduced by activation of transcription factor $\mathrm{NF}-\mathrm{kB}$ that results in activation of various genes involved in cell proliferation and death, inflammation, and cancer [55]. Studies have shown that TNF- $\alpha$ promotes hepatocyte proliferation rather than their death when it is administrated to animals or incubated with hepatocytes in vitro [56]. The HCV NS3 protein inhibits TNF- $\alpha$-induced NFKB activation via binding to linear ubiquitinin chain assembly complex (LUBAC) [57]. On the other hand, IL-6 plays a central role as a distress cytokine during inflammation in the body. During HCV infection, the production of IL- 6 and IFN- $\beta$ from B cells increases. These events follow a strong activation of TLRs, especially TLR4 which activates NFKB, and triggers IL-6 production by binding the promotor region of the IL-6 gene [58]. IL-6 can help self-production through binding to a heterodimeric IL-6R/gp130 complex. This heterodimer triggers an activation process and the JAK-STAT3 pathway retains the cell cycle progression [59]. It has been reported that HCV induces inflammation through a significant increase in serum IL-6 levels in chronically infected patients [60]. In addition, HCV infection may actively promote the development of hepatic steatosis via the paracrine effect of secreted IL-8 [61]. These proinflammatory cytokines lead to the development of chronic inflammation for HCV persistence in infected cells. HCV-induced inflammation through IL-6 activates JAK-STAT3 to retain cell cycle progression.

Cells of the innate immune system, such as the dendritic cell (DC), may be poor stimulators of $\mathrm{T}$ cells. On the other hand, E2-treated macrophages significantly decrease expression of M1 phenotype markers (IFN- $\gamma$, IL-6, and TNF- $\alpha$ ) as compared with untreated macrophages. In contrast, increased expression of M2 markers (MRC1 or CD206, IL-10, TGM2) is observed in HCV E2-treated macrophages [62]. HCV antigens may regulate inflammatory regulators differently based on the cell types and may be a mechanism by which HCV target cells impair development of a strong adaptive immunity. 


\section{Modulation of Natural Killer Cell Response}

Natural killer (NK) cells are a large proportion of the granular lymphocyte population in the human liver, remain in a functionally hyporesponsive state, but rapidly induce an innate immune response to viral infection [63-65]. NK cells either directly target infected hepatocytes, or act indirectly by influencing other immune cells such as DCs or T cells for virus clearance. The interaction between NK cells and HCV-infected hepatocytes may result in the regulation of NK cell activity. There is an activation of NK cells in the acute phase of $\mathrm{HCV}$ infection indicating a role in the innate immune response. Genetic studies reveal that interaction between human leukocyte antigen HLA-C and specific killer immunoglobulin-like receptor KIR2DL3 results in spontaneous cytotoxicity of NK cells in HCV infection [66,67]. Indeed, myeloid dendritic cells (mDCs) produce IL-12 in response to HCV-mediated TLR-3 signaling and induce IFN- $\gamma$ secretion by NK cells $[68,69]$. pDCs sense HCV RNA in exosomes generated from the infected hepatoma cells and secrete IFN- $\alpha$ which activates NK cells [41]. On the other hand, chronic HCV-infected patients have shown perturbations in NK cell frequency and function [70]. NK cell frequencies in peripheral blood are reduced in chronic HCV infection when compared to healthy individuals. IFN- $\gamma$ is the major cytokine that NK cells secrete and is a critical factor for inhibition of viral replication. Concurrent engagement of activating receptors and cytokine receptors on NK cells induces IFN- $\gamma$ secretion. Therefore, a decrease in activating receptor expression would likely be correlated with IFN- $\gamma$ inhibition by CD56 $6^{\text {dim }}$ NK cells [63]. A polarized NK cell phenotype is induced by chronic exposure to HCV-induced TFN- $\alpha$. This phenotype may contribute to liver injury through TRAIL expression and cytotoxicity, whereas the lack of increase in IFN- $\gamma$ production may facilitate the inability to clear HCV [71,72].

HCV E2 protein binds to the NK CD81 receptor, decreasing the release of IFN- $\gamma$ and cytotoxic granules [73,74]. NKG2D from NK cells interacts with hepatocyte major histocompatibility complex class I-related chains A and B (MICA/B) as one of the ligands [75]. HCV affects NK cell activity through direct cell-to-cell interaction via CD81 or NK cell receptors or in an indirect manner via cytokine or TRAIL release [73,76-78]. NK cells exposed to cell culture-grown HCV-infected hepatocytes become unable to increase complement synthesis due to inhibition of MICA/B protein expression [79]. Further, NKG2D expression is lowered in circulating NK cells from patients with chronic hepatitis $C$ [80]. A remarkable increase of hepatic NK cells for expansion of resident liver NK cells and/or recruitment of NK cells from the blood occurs during infection [81]. HCV NS5A protein stimulates monocytes through TLR-4 and induces secretion of IL-10, which subsequently stimulates the secretion of transforming growth factor (TGF)- $\beta$ and downregulates NKG2D on the NK cell surface, resulting in functional impairment of NK cells [82]. HCV NS2 and NS5B proteins are also responsible for $\mathrm{HCV}$-associated decrease in MICA/B, resulting in a loss of the $\mathrm{C} 3 / \mathrm{C} 4$ complement components. This inactivation of the complement system leads to impairment of NK cell activation and attenuates adaptive immune response [79]. Furthermore, the complement system indirectly promotes dendritic cell-mediated NK cell activation by inducing TGF- $\beta 1$, and involves the inflammatory response [83]. Together, this information suggests that the functional impairment of NK cells is associated with the evolution of HCV chronicity.

\section{Activation of Complement System}

The complement system is a series of plasma proteins which work with the innate immune system for targeting and eliminating the invading pathogens. The complement plays a prominent role in the linkage of innate and adaptive immunity. The liver is the main source of complement and hepatocytes are the primary sites for synthesis of complement components in vivo [84]. Liver damage may diminish capacity of complement synthesis in patients. HCV successfully escapes the complement response for persistent infection by regulating complement components. $\mathrm{C} 1 \mathrm{q}$ is the initial component of the classical complement system and plays a protecting role in viral infection. The binding of $\mathrm{C} 1 \mathrm{q}$ to the $\mathrm{C} 1 \mathrm{q}$ receptor, $\mathrm{gC1qR}$, plays a role in resolution of infection [85]. HCV Core protein interacts with $\mathrm{gC1qR}$ which can cause pathogenic effects in vivo. The receptor circulates as a complex with HCV 
Core protein and sequesters the $\mathrm{C} 4 \mathrm{~d}$ cleavage to prevent complement-mediated lysis [86]. The $\mathrm{gCl} \mathrm{qR}$ expression on $\mathrm{CD}^{+} \mathrm{T}$ cells influences the outcome of $\mathrm{HCV}$ infection [87]. HCV increases the frequency of $\mathrm{gCl} 1 \mathrm{qR}^{+} \mathrm{CD} 4^{+} \mathrm{T}$ cells, and viral persistence maintains this frequency at the late phase of infection, while individuals resolving $\mathrm{HCV}$ infection do not. $\mathrm{HCV}$ has evolved mechanisms to evade immune activation, including complement response. Serum C3 level is depleted in HCV-infected cirrhotic patients [88]. Dumestre-Perard et al. [89] reported that C4 activity is significantly lower and the level of different complement components is depleted in patients with chronic HCV infection. Our study revealed that HCV E2 envelope glycoprotein suppresses $\mathrm{C} 3$ expression and impairs macrophage and $\mathrm{DC}$ maturation for antigen presentation and normal $\mathrm{CD} 4^{+} \mathrm{T}$ cell stimulation [90]. HCV suppresses C3, C4 and C9 complement component synthesis and impairs membrane attack complex (MAC) [91] for attenuation of MAC-mediated microbicidal activity (Figure 1). HCV induces CD55/DAF as a negative regulator of complement activation. CD55 inhibits the formation and dissociation of C3/C5 convertases. C3 complement component is an important mediator of the humoral and T-cell immune responses [92-95]. C3 facilitates antigen uptake/presentation and immune cell priming. Receptors interacting with various activation fragments of $\mathrm{C} 3$ are expressed on a wide variety of cell types associated with immune function. $\mathrm{C} 3$ activity is required for optimal expansion of $\mathrm{CD} 8^{+} \mathrm{T}$ cells during a systemic viral infection [96]. HCV Core protein upregulates CD55 expression on the cell surface and inhibits CDC [97]. Some tumors do not solely express a single variant of CD55, but also express different isoforms of the protein [98]. Thus, the induction of cell-associated and secretory CD55 expression by HCV infection in immortalized human hepatocytes may limit complement-mediated damage of infected cells and the cell-associated microenvironment. Antibodies against cancer cell surface proteins enhance ADCC and CDC [97,99]. Our observations suggest that tumorigenic immortalized human hepatocytes induced by HCV in culture become susceptible to complement- and antibodydependent killing in the presence of CD55 blocking antibody [97]. These studies highlight the cooperative approach of $\mathrm{HCV}$ proteins in controlling of host NK cell and complement components or complement-associated CD55 protein functions to perpetuate virus fitness. Together, the information suggests a multifaceted approach undertaken by HCV to impair complement functions.

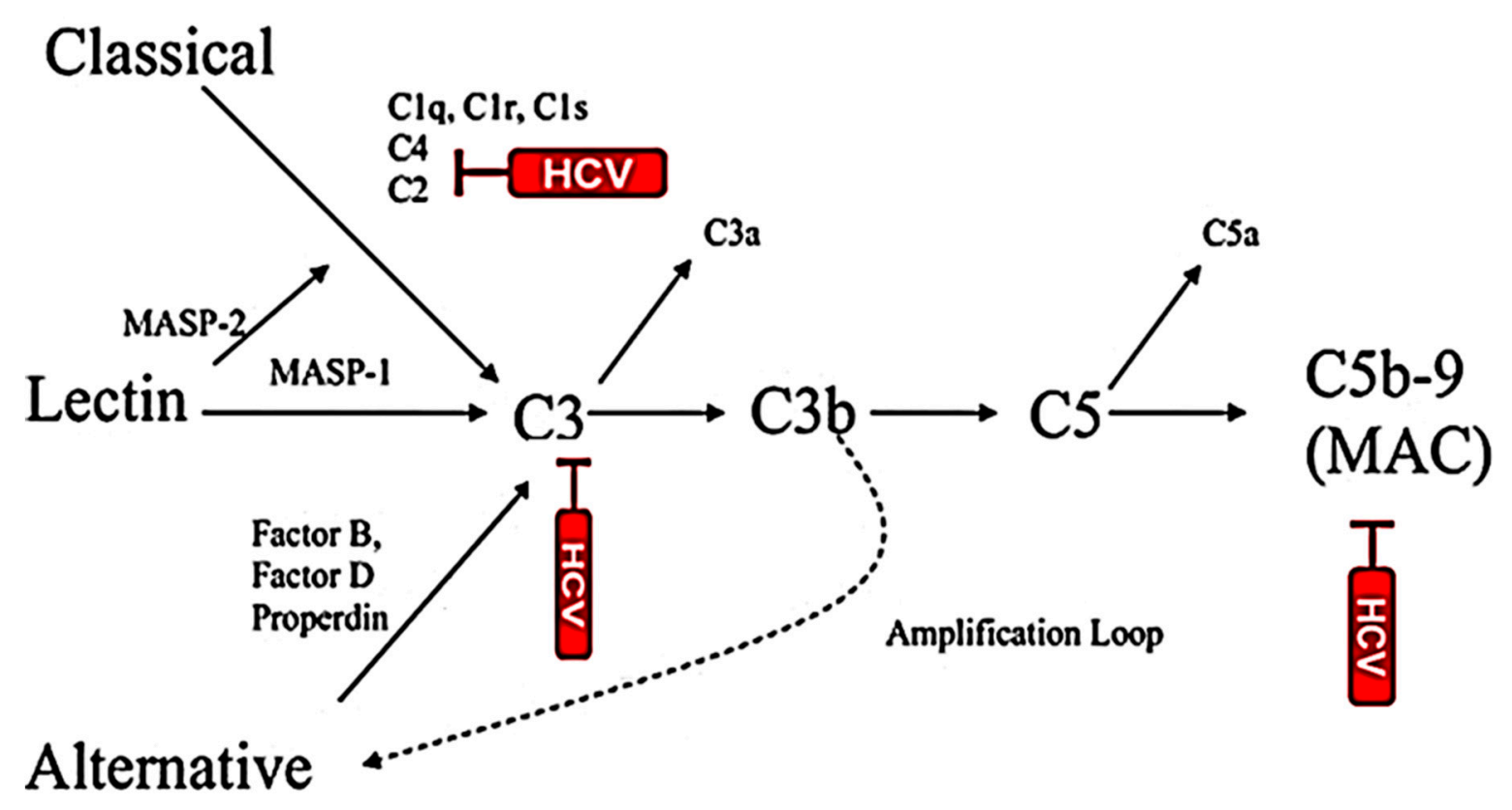

Figure 1. Inhibition of multiple complement components by HCV. Reduced complement function may exhibit attenuated MAC-mediated antimicrobial effect. 


\section{Innate Immunity Helping Adaptive Immune Response}

NK cells constitute a bridge between innate and adaptive immune responses. NK cell-mediated DC activation interplays in priming the adaptive immune response. During acute HCV infection, DCs of the host should interact with the viral proteins to contribute the $\mathrm{CD} 4^{+} \mathrm{T}$ and $\mathrm{CD} 8^{+} \mathrm{T}$ cell responses for clearance or persistence of infection. DCs expressing HCV Core or NS3 protein show an impaired antigen presentation and maturation, which renders DCs unable to trigger T-cell activation [100]. mDCs generated from HCV-infected patients display a reduced CD86 and/or IL-12 expression, and impaired stimulatory potential against allogenic $\mathrm{CD} 4^{+} \mathrm{T}$ cells [101]. In addition, mDCs from chronic hepatitis $\mathrm{C}$ patients exhibit a high cytotoxic activity and can kill T cells through the TRAIL pathway [102]. Additionally, an increased plasma level of HCV Core protein in chronic HCV infection causes less IFN- $\alpha$ production due to a reduced frequency of circulating pDC [32]. Mucosal-associated invariant T (MAIT) cells represent a conserved subset of $\mathrm{T}$ cells and participate in the innate immune response for protection against infection [103]. Recent studies have shown that in chronic HCV infection, the number of MAIT cells significantly decreases, and residual MAIT cells seem to suffer from immune exhaustion and senescence, which would contribute to the diminished innate defense and facilitate HCV persistence for liver disease progression [104].

The $\mathrm{CD} 8^{+} \mathrm{T}$ cell is not very effective in chronic hepatitis $\mathrm{C}$ patients. Impairment of $\mathrm{CD} 8^{+} \mathrm{T}$ cell response was noticed in transgenic mice where the expression of HCV Core was directed to the liver, and followed through the suppression of IFN- $\gamma$, TNF- $\alpha$, and granzyme B production [105]. Liver-infiltrating lymphocytes obtained from chronic HCV-infected patients suggest high levels of PD-1 and a low level of CD127 expression, resulting in a suppressed function of HCV-specific CD8 ${ }^{+} \mathrm{T}$ cells $[106,107]$. These results suggest that regulation of the PD-1 pathway is essential for impairment of HCV Core-mediated T-cell responses. Robust and broad HCV-specific CD8 ${ }^{+} \mathrm{T}$-cell responses are critical for spontaneous viral resolution in acute infection, and help in maintaining by $\mathrm{CD} 4^{+} \mathrm{T}$ cells. The HCV E2 protein and a short RNA fragment encoded by E2 have been found to hinder PD-1, cytotoxic T-lymphocyte antigen 4 (CTL-4) and Tim-3 expression, respectively [108,109]. Inhibition of PD-1, Tim-3, and CTL-4 pathways can cause imbalance between Th17 and Treg cells, which might lead to the failure of the $\mathrm{HCV}$-specific $\mathrm{CD} 4^{+} \mathrm{T}$-cell response [110]. Several studies have reported that HCV can induce myeloid-derived suppressor cells, cytokines like IL-10 and TGF- $\beta$, resulting in a promotion of Treg development and suppression of CD4 ${ }^{+}$T-cell function $[109,111]$. Interestingly, the HCV Core protein activates CD69 expression to promote B-cell proliferation and increases IgG and IgM production with diminished SOCS-1 signaling, followed by downregulation of MHC class II expression. In this way, HCV affects the antigen-presenting function of B cells, but not Ig production [112,113], and dysfunction of adaptive immune response allows establishment of the persistent HCV infection in a host. The modulation of immune functions by HCV is shown in a simplified cartoon (Figure 2). 


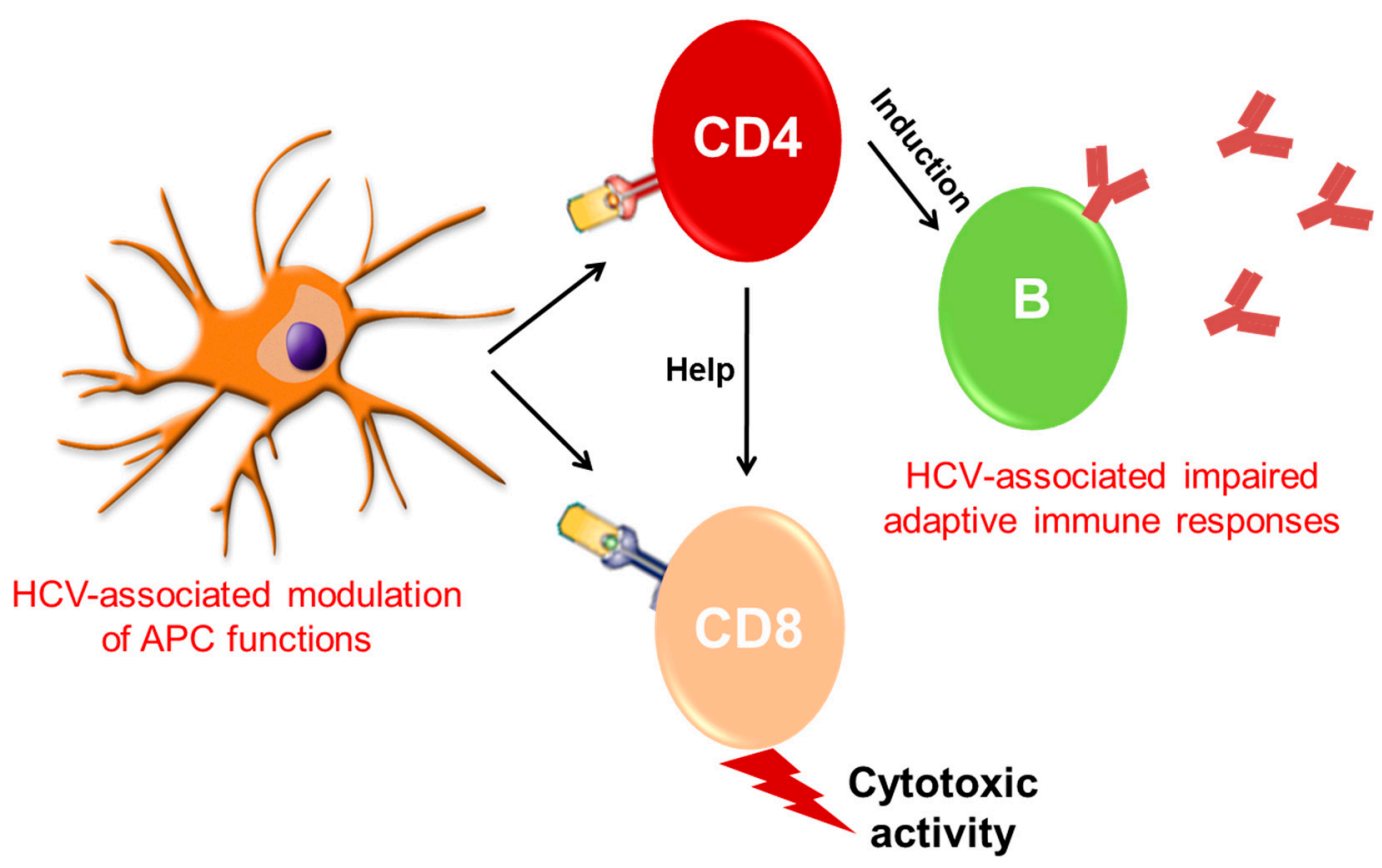

Figure 2. Modulation of $\mathrm{APC}$ and $\mathrm{CD} 4^{+} \mathrm{T} / \mathrm{CD} 8^{+} \mathrm{T}$-cell functions by $\mathrm{HCV}$ and impairment of adaptive immune responses.

\section{Conclusions}

HCV makes successful strategies to antagonize the host immune responses and often persists as chronic infection leading to life-threatening end-stage liver disease. In this review, we have discussed how the HCV antigen is sensed to the host by the innate immune system and would inhibit or prime the adaptive immunity. HCV modulates inflammatory responses in different cell populations and microenvironments within the host. DCs or macrophages are critical for antigen presentation, and regulation of these cells may impair adaptive immune response. Elucidating the mechanisms by which HCV fails to activate DC or modulate macrophage function and impair generation of a strong adaptive immunity will identify strategies for prevention of viral persistence. The foremost accomplishment of HCV research is the discovery of interferon-free DAAs with a sustained virological response. This advanced antiviral therapy is well tolerated and successfully works on pan-genotypes in eliminating HCV infection. However, recent reports suggest emergence of viral resistance against these therapeutic compounds [114]. This may allow continued HCV transmission in high-risk groups and resource-constrained settings due to limited surveillance. In addition, HCV infection often causes a silent disease and late diagnosis may lead to progression of advanced liver disease. Further, detection of HCV carriers, lack of immunity against reinfection, insufficient access to DAA therapy, uncertainty about the magnitude of viral resistance development, and continued risk for severe liver damage are the major hurdles to overcome. We also need to identify steps for augmenting immune responses, and developing a protective vaccine for $\mathrm{HCV}$ is an unmet medical necessity. Global eradication of $\mathrm{HCV}$ will not likely be possible without a robust vaccine.

Author Contributions: T.P., R.B.R. and R.R. designed the study, collected the reported research results, represented and interpreted the reported research results and wrote the manuscript.

Funding: Our work was supported by research grants DK113645 and DK081817 from the National Institutes of Health.

Acknowledgments: We apologize to all our colleagues whose work we could not cite for space limitations.

Conflicts of Interest: The authors declare no conflict of interest. 


\section{Abbreviations}

$\begin{array}{ll}\text { ADCC } & \text { antibody-dependent cell cytotoxicity } \\ \text { APC } & \text { antigen-presenting cell } \\ \text { CDC } & \text { complement-dependent lysis } \\ \text { DAA } & \text { direct-acting antiviral } \\ \text { DAMP } & \text { danger-associated molecular patterns } \\ \text { DC } & \text { dendritic cells } \\ \text { HCC } & \text { hepatocellular carcinoma } \\ \text { HCV } & \text { hepatitis C virus } \\ \text { IFN } & \text { interferon } \\ \text { ISG } & \text { interferon-stimulated genes } \\ \text { ISGF3 } & \text { interferon-stimulated gene factor 3 } \\ \text { ISRE } & \text { interferon-stimulated response element } \\ \text { MAC } & \text { membrane attack complex } \\ \text { MAIT } & \text { mucosal-associated invariant T } \\ \text { MASP } & \text { mannose-associated serine protease } \\ \text { mDCs } & \text { monocyte-derived dendritic cells } \\ \text { NK } & \text { natural killer } \\ \text { PAMP } & \text { pathogen-associated molecular patterns } \\ \text { PD-1 } & \text { programmed cell death protein-1 } \\ \text { PKR } & \text { protein kinase R } \\ \text { PRRs } & \text { pattern-recognition receptors } \\ \text { RIG-I } & \text { retinoic acid inducible gene-I } \\ \text { SVR } & \text { toll-like receptor } \\ \text { TLR } & \text { untranslated region } \\ \text { UTR } & \end{array}$

\section{References}

1. Choo, Q.L.; Kuo, G.; Weiner, A.J.; Overby, L.R.; Bradley, D.W.; Houghton, M. Isolation of a cDNA clone derived from a blood-borne non-A, non-B viral hepatitis genome. Science 1989, 244, 359-362. [CrossRef] [PubMed]

2. Pfaender, S.; Brown, R.J.; Pietschmann, T.; Steinmann, E. Natural reservoirs for homologs of hepatitis C virus. Emerg. Microbes Infect. 2014, 3, e21. [CrossRef]

3. Lindenbach, B.D.; Rice, C.M. The ins and outs of hepatitis C virus entry and assembly. Nat. Rev. Microbiol. 2013, 11, 688-700. [CrossRef]

4. Smith, D.B.; Simmonds, P. Classification and Genomic Diversity of Enterically Transmitted Hepatitis Viruses. Cold Spring Harb. Perspect. Med. 2018, 8. [CrossRef] [PubMed]

5. Torre, L.A.; Bray, F.; Siegel, R.L.; Ferlay, J.; Lortet-Tieulent, J.; Jemal, A. Global cancer statistics, 2012. CA Cancer J. Clin. 2015, 65, 87-108. [CrossRef] [PubMed]

6. Petruzziello, A.; Marigliano, S.; Loquercio, G.; Cozzolino, A.; Cacciapuoti, C. Global epidemiology of hepatitis $C$ virus infection: An up-date of the distribution and circulation of hepatitis $C$ virus genotypes. World J. Gastroenterol. 2016, 22, 7824-7840. [CrossRef]

7. Kanwal, F.; Hoang, T.; Kramer, J.R.; Asch, S.M.; Goetz, M.B.; Zeringue, A.; Richardson, P.; El-Serag, H.B. Increasing prevalence of HCC and cirrhosis in patients with chronic hepatitis $\mathrm{C}$ virus infection. Gastroenterology 2011, 140, 1182-1188.e1. [CrossRef] [PubMed]

8. Levrero, M. Viral hepatitis and liver cancer: The case of hepatitis C. Oncogene 2006, 25, 3834-3847. [CrossRef]

9. Pinter, M.; Sieghart, W. Long-term remission in advanced stage hepatocellular carcinoma? A chance for cure? MEMO 2018, 11, 185-192. [CrossRef]

10. Sherman, M. Hepatocellular carcinoma: Epidemiology, surveillance, and diagnosis. Semin. Liver Dis. 2010, 30, 3-16. [CrossRef]

11. Szabo, G.; Saha, B.; Bukong, T.N. Alcohol and HCV: Implications for liver cancer. Adv. Exp. Med. Biol. 2015, 815, 197-216. 
12. Palumbo, E. Pegylated interferon and ribavirin treatment for hepatitis $\mathrm{C}$ virus infection. Ther. Adv. Chronic Dis. 2011, 2, 39-45. [CrossRef]

13. AASLD/IDSA HCV Guidance Panel. Hepatitis C guidance: AASLD-IDSA recommendations for testing, managing, and treating adults infected with hepatitis C virus. Hepatology 2015, 62, 932-954. [CrossRef] [PubMed]

14. Au, J.S.; Pockros, P.J. Novel therapeutic approaches for hepatitis C. Clin. Pharmacol. Ther. 2014, 95, 78-88. [CrossRef] [PubMed]

15. Ray, R.B.; Ray, R. Hepatitis C virus manipulates humans as its favorite host for long term relationship. Hepatology 2019, 69, 889-900. [CrossRef] [PubMed]

16. Kwon, Y.C.; Ray, R.B.; Ray, R. Hepatitis C virus infection: Establishment of chronicity and liver disease progression. EXCLI J. 2014, 13, 977-996. [PubMed]

17. Akira, S.; Uematsu, S.; Takeuchi, O. Pathogen recognition and innate immunity. Cell 2006, 124, $783-801$. [CrossRef]

18. Heim, M.H. Innate immunity and HCV. J. Hepatol. 2013, 58, 564-574. [CrossRef]

19. Schnell, G.; Loo, Y.M.; Marcotrigiano, J.; Gale, M., Jr. Uridine composition of the poly-U/UC tract of HCV RNA defines non-self-recognition by RIG-I. PLoS Pathog. 2012, 8, e1002839. [CrossRef] [PubMed]

20. Rosen, H.R. Emerging concepts in immunity to hepatitis $C$ virus infection. J. Clin. Investig. 2013, 123, 4121-4130. [CrossRef] [PubMed]

21. Reikine, S.; Nguyen, J.B.; Modis, Y. Pattern Recognition and Signaling Mechanisms of RIG-I and MDA5. Front. Immunol. 2014, 5, 342. [CrossRef] [PubMed]

22. Gale, M.J., Jr.; Korth, M.J.; Katze, M.G. Repression of the PKR protein kinase by the hepatitis C virus NS5A protein: A potential mechanism of interferon resistance. Clin. Diagn. Virol. 1998, 10, 157-162. [CrossRef]

23. Taylor, D.R.; Shi, S.T.; Romano, P.R.; Barber, G.N.; Lai, M.M. Inhibition of the interferon-inducible protein kinase PKR by HCV E2 protein. Science 1999, 285, 107-110. [CrossRef] [PubMed]

24. Bode, J.G.; Ludwig, S.; Ehrhardt, C.; Albrecht, U.; Erhardt, A.; Schaper, F.; Heinrich, P.C.; Haussinger, D. IFN-alpha antagonistic activity of HCV core protein involves induction of suppressor of cytokine signaling-3. FASEB J. 2003, 17, 488-490. [CrossRef] [PubMed]

25. Lan, K.H.; Lan, K.L.; Lee, W.P.; Sheu, M.L.; Chen, M.Y.; Lee, Y.L.; Yen, S.H.; Chang, F.Y.; Lee, S.D. HCV NS5A inhibits interferon-alpha signaling through suppression of STAT1 phosphorylation in hepatocyte-derived cell lines. J. Hepatol. 2007, 46, 759-767. [CrossRef]

26. Cheon, H.; Stark, G.R. Unphosphorylated STAT1 prolongs the expression of interferon-induced immune regulatory genes. Proc. Natl. Acad. Sci. USA 2009, 106, 9373-9378. [CrossRef] [PubMed]

27. Raychoudhuri, A.; Shrivastava, S.; Steele, R.; Dash, S.; Kanda, T.; Ray, R.; Ray, R.B. Hepatitis C virus infection impairs IRF-7 translocation and Alpha interferon synthesis in immortalized human hepatocytes. J. Virol. 2010, 84, 10991-10998. [CrossRef] [PubMed]

28. Foy, E.; Li, K.; Wang, C.; Sumpter, R., Jr.; Ikeda, M.; Lemon, S.M.; Gale, M., Jr. Regulation of interferon regulatory factor-3 by the hepatitis C virus serine protease. Science 2003, 300, 1145-1148. [CrossRef] [PubMed]

29. Horner, S.M.; Gale, M., Jr. Regulation of hepatic innate immunity by hepatitis C virus. Nat. Med. 2013, 19, 879-888. [CrossRef] [PubMed]

30. Kim, S.J.; Syed, G.H.; Khan, M.; Chiu, W.W.; Sohail, M.A.; Gish, R.G.; Siddiqui, A. Hepatitis C virus triggers mitochondrial fission and attenuates apoptosis to promote viral persistence. Proc. Natl. Acad. Sci. USA 2014, 111, 6413-6418. [CrossRef]

31. Enomoto, N.; Sakuma, I.; Asahina, Y.; Kurosaki, M.; Murakami, T.; Yamamoto, C.; Ogura, Y.; Izumi, N.; Marumo, F.; Sato, C. Mutations in the nonstructural protein 5A gene and response to interferon in patients with chronic hepatitis C virus 1b infection. N. Engl. J. Med. 1996, 334, 77-81. [CrossRef] [PubMed]

32. Dolganiuc, A.; Chang, S.; Kodys, K.; Mandrekar, P.; Bakis, G.; Cormier, M.; Szabo, G. Hepatitis C virus (HCV) core protein-induced, monocyte-mediated mechanisms of reduced IFN-alpha and plasmacytoid dendritic cell loss in chronic HCV infection. J. Immunol. 2006, 177, 6758-6768. [CrossRef]

33. Wohnsland, A.; Hofmann, W.P.; Sarrazin, C. Viral determinants of resistance to treatment in patients with hepatitis C. Clin. Microbiol. Rev. 2007, 20, 23-38. [CrossRef] [PubMed]

34. Heim, M.H.; Bochud, P.Y.; George, J. Host-hepatitis C viral interactions: The role of genetics. J. Hepatol. 2016, 65, S22-S32. [CrossRef] 
35. Matsuura, K.; Tanaka, Y. Host genetic variants influencing the clinical course of hepatitis $C$ virus infection. J. Med. Virol. 2016, 88, 185-195. [CrossRef] [PubMed]

36. Lee, C.M.; Hu, T.H.; Lu, S.N.; Wang, J.H.; Hung, C.H.; Chen, C.H.; Yen, Y.H. Peripheral blood toll-like receptor 4 correlates with rapid virological response to pegylated-interferon and ribavirin therapy in hepatitis $\mathrm{C}$ genotype 1 patients. BMC Gastroenterol. 2016, 16, 73. [CrossRef] [PubMed]

37. Dolganiuc, A.; Oak, S.; Kodys, K.; Golenbock, D.T.; Finberg, R.W.; Kurt-Jones, E.; Szabo, G. Hepatitis C core and nonstructural 3 proteins trigger toll-like receptor 2-mediated pathways and inflammatory activation. Gastroenterology 2004, 127, 1513-1524. [CrossRef]

38. Wang, N.; Liang, Y.; Devaraj, S.; Wang, J.; Lemon, S.M.; Li, K. Toll-like receptor 3 mediates establishment of an antiviral state against hepatitis C virus in hepatoma cells. J. Virol. 2009, 83, 9824-9834. [CrossRef]

39. Takahasi, K.; Horiuchi, M.; Fujii, K.; Nakamura, S.; Noda, N.N.; Yoneyama, M.; Fujita, T.; Inagaki, F. Ser386 phosphorylation of transcription factor IRF-3 induces dimerization and association with $\mathrm{CBP} / \mathrm{p} 300$ without overall conformational change. Genes Cells 2010, 15, 901-910. [CrossRef]

40. Abe, T.; Kaname, Y.; Hamamoto, I.; Tsuda, Y.; Wen, X.; Taguwa, S.; Moriishi, K.; Takeuchi, O.; Kawai, T.; Kanto, T.; et al. Hepatitis C virus nonstructural protein 5A modulates the toll-like receptor-MyD88-dependent signaling pathway in macrophage cell lines. J. Virol. 2007, 81, 8953-8966. [CrossRef] [PubMed]

41. Dreux, M.; Garaigorta, U.; Boyd, B.; Decembre, E.; Chung, J.; Whitten-Bauer, C.; Wieland, S.; Chisari, F.V. Short-range exosomal transfer of viral RNA from infected cells to plasmacytoid dendritic cells triggers innate immunity. Cell Host Microbe 2012, 12, 558-570. [CrossRef] [PubMed]

42. Wang, C.H.; Eng, H.L.; Lin, K.H.; Chang, C.H.; Hsieh, C.A.; Lin, Y.L.; Lin, T.M. TLR7 and TLR8 gene variations and susceptibility to hepatitis $C$ virus infection. PLoS ONE 2011, 6, e26235. [CrossRef]

43. Fernandez-Rodriguez, A.; Berenguer, J.; Jimenez-Sousa, M.A.; Garcia-Alvarez, M.; Aldamiz-Echevarria, T.; Pineda-Tenor, D.; Diez, C.; de la Barrera, J.; Bellon, J.M.; Briz, V.; et al. Toll-like receptor 8 (TLR8) polymorphisms are associated with non-progression of chronic hepatitis C in HIV/HCV coinfected patients. Infect. Genet. Evol. 2015, 36, 339-344. [CrossRef]

44. Medzhitov, R. Origin and physiological roles of inflammation. Nature 2008, 454, 428-435. [CrossRef] [PubMed]

45. Schroder, K.; Tschopp, J. The inflammasomes. Cell 2010, 140, 821-832. [CrossRef]

46. Van de Veerdonk, F.L.; Netea, M.G.; Dinarello, C.A.; Joosten, L.A. Inflammasome activation and IL-1beta and IL-18 processing during infection. Trends Immunol. 2011, 32, 110-116. [CrossRef] [PubMed]

47. Chattergoon, M.A.; Levine, J.S.; Latanich, R.; Osburn, W.O.; Thomas, D.L.; Cox, A.L. High plasma interleukin-18 levels mark the acute phase of hepatitis C virus infection. J. Infect. Dis. 2011, 204, 1730-1740. [CrossRef] [PubMed]

48. Shrivastava, S.; Mukherjee, A.; Ray, R.; Ray, R.B. Hepatitis C virus induces interleukin-1beta (IL-1beta)/IL-18 in circulatory and resident liver macrophages. J. Virol. 2013, 87, 12284-12290. [CrossRef]

49. Negash, A.A.; Ramos, H.J.; Crochet, N.; Lau, D.T.; Doehle, B.; Papic, N.; Delker, D.A.; Jo, J.; Bertoletti, A.; Hagedorn, C.H.; et al. IL-1beta production through the NLRP3 inflammasome by hepatic macrophages links hepatitis C virus infection with liver inflammation and disease. PLoS Pathog. 2013, 9, e1003330. [CrossRef]

50. Chattergoon, M.A.; Latanich, R.; Quinn, J.; Winter, M.E.; Buckheit, R.W.; 3rd Blankson, J.N.; Pardoll, D.; Cox, A.L. HIV and HCV activate the inflammasome in monocytes and macrophages via endosomal Toll-like receptors without induction of type 1 interferon. PLoS Pathog. 2014, 10, e1004082. [CrossRef]

51. Sasaki, R.; Devhare, P.B.; Steele, R.; Ray, R.; Ray, R.B. Hepatitis C virus-induced CCL5 secretion from macrophages activates hepatic stellate cells. Hepatology 2017, 66, 746-757. [CrossRef]

52. Decker, K. Biologically active products of stimulated liver macrophages (Kupffer cells). Eur. J. Biochem. 1990, 192, 245-261. [CrossRef]

53. Tacke, F.; Luedde, T.; Trautwein, C. Inflammatory pathways in liver homeostasis and liver injury. Clin. Rev. Allergy Immunol. 2009, 36, 4-12. [CrossRef] [PubMed]

54. Lee, J.; Tian, Y.; Chan, S.T.; Kim, J.Y.; Cho, C.; Ou, J.H. TNF-alpha Induced by Hepatitis C Virus via TLR7 and TLR8 in Hepatocytes Supports Interferon Signaling via an Autocrine Mechanism. PLoS Pathog. 2015, 11, e1004937. [CrossRef]

55. Karin, M. NF-kappaB as a critical link between inflammation and cancer. Cold Spring Harb. Perspect. Biol. 2009, 1, a000141. [CrossRef] [PubMed] 
56. Diehl, A.M.; Yin, M.; Fleckenstein, J.; Yang, S.Q.; Lin, H.Z.; Brenner, D.A.; Westwick, J.; Bagby, G.; Nelson, S. Tumor necrosis factor-alpha induces c-jun during the regenerative response to liver injury. Am. J. Physiol. 1994, 267, G552-G561. [CrossRef] [PubMed]

57. Chen, Y.; He, L.; Peng, Y.; Shi, X.; Chen, J.; Zhong, J.; Chen, X.; Cheng, G.; Deng, H. The hepatitis C virus protein NS3 suppresses TNF-alpha-stimulated activation of NF-kappaB by targeting, LUBAC. Sci. Signal. 2015, 8, ra118. [CrossRef] [PubMed]

58. Libermann, T.A.; Baltimore, D. Activation of interleukin-6 gene expression through the NF-kappa B transcription factor. Mol. Cell. Biol. 1990, 10, 2327-2334. [CrossRef] [PubMed]

59. Grivennikov, S.; Karin, M. Autocrine IL-6 signaling: A key event in tumorigenesis? Cancer Cell 2008, 13, 7-9. [CrossRef] [PubMed]

60. Malaguarnera, M.; Di Fazio, I.; Romeo, M.A.; Restuccia, S.; Laurino, A.; Trovato, B.A. Elevation of interleukin 6 levels in patients with chronic hepatitis due to hepatitis C virus. J. Gastroenterol. 1997, 32, 211-215. [CrossRef]

61. Koike, K.; Moriya, K. Metabolic aspects of hepatitis C viral infection: Steatohepatitis resembling but distinct from NASH. J. Gastroenterol. 2005, 40, 329-336. [CrossRef] [PubMed]

62. Kwon, Y.C.; Meyer, K.; Peng, G.; Chatterjee, S.; Hoft, D.F.; Ray, R. Hepatitis C virus E2 envelope glycoprotein induces an immunoregulatory phenotype in macrophages. Hepatology 2018. [CrossRef] [PubMed]

63. Caligiuri, M.A. Human natural killer cells. Blood 2008, 112, 461-469. [CrossRef] [PubMed]

64. Nellore, A.; Fishman, J.A. NK cells, innate immunity and hepatitis C infection after liver transplantation. Clin. Infect. Dis. 2011, 52, 369-377. [CrossRef]

65. Krueger, P.D.; Lassen, M.G.; Qiao, H.; Hahn, Y.S. Regulation of NK cell repertoire and function in the liver. Crit. Rev. Immunol. 2011, 31, 43-52. [CrossRef] [PubMed]

66. Ahlenstiel, G.; Martin, M.P.; Gao, X.; Carrington, M.; Rehermann, B. Distinct KIR/HLA compound genotypes affect the kinetics of human antiviral natural killer cell responses. J. Clin. Investig. 2008, 118, 1017-1026. [CrossRef] [PubMed]

67. Cariani, E.; Pilli, M.; Zerbini, A.; Rota, C.; Olivani, A.; Zanelli, P.; Zanetti, A.; Trenti, T.; Ferrari, C.; Missale, G. HLA and killer immunoglobulin-like receptor genes as outcome predictors of hepatitis $C$ virus-related hepatocellular carcinoma. Clin. Cancer Res. 2013, 19, 5465-5473. [CrossRef] [PubMed]

68. Siegal, F.P.; Kadowaki, N.; Shodell, M.; Fitzgerald-Bocarsly, P.A.; Shah, K.; Ho, S.; Antonenko, S.; Liu, Y.J. The nature of the principal type 1 interferon-producing cells in human blood. Science 1999, 284, 1835-1837. [CrossRef]

69. Velazquez, V.M.; Hon, H.; Ibegbu, C.; Knechtle, S.J.; Kirk, A.D.; Grakoui, A. Hepatic enrichment and activation of myeloid dendritic cells during chronic hepatitis C virus infection. Hepatology 2012, 56, 2071-2081. [CrossRef] [PubMed]

70. Tian, Z.; Chen, Y.; Gao, B. Natural killer cells in liver disease. Hepatology 2013, 57, 1654-1662. [CrossRef]

71. Elliott, J.M.; Yokoyama, W.M. Unifying concepts of MHC-dependent natural killer cell education. Trends Immunol. 2011, 32, 364-372. [CrossRef] [PubMed]

72. Brenner, C.; Galluzzi, L.; Kepp, O.; Kroemer, G. Decoding cell death signals in liver inflammation. J. Hepatol. 2013, 59, 583-594. [CrossRef] [PubMed]

73. Crotta, S.; Stilla, A.; Wack, A.; D’Andrea, A.; Nuti, S.; D’Oro, U.; Mosca, M.; Filliponi, F.; Brunetto, R.M.; Bonino, F.; et al. Inhibition of natural killer cells through engagement of CD81 by the major hepatitis $\mathrm{C}$ virus envelope protein. J. Exp. Med. 2002, 195, 35-41. [CrossRef]

74. Tseng, C.T.; Klimpel, G.R. Binding of the hepatitis C virus envelope protein E2 to CD81 inhibits natural killer cell functions. J. Exp. Med. 2002, 195, 43-49. [CrossRef] [PubMed]

75. Jinushi, M.; Takehara, T.; Tatsumi, T.; Kanto, T.; Groh, V.; Spies, T.; Suzuki, T.; Miyagi, T.; Hayashi, N. Autocrine/paracrine IL-15 that is required for type I IFN-mediated dendritic cell expression of MHC class I-related chain A and B is impaired in hepatitis C virus infection. J. Immunol. 2003, 171, 5423-5429. [CrossRef]

76. Golden-Mason, L.; Rosen, H.R. Natural killer cells: Primary target for hepatitis $C$ virus immune evasion strategies? Liver Transpl. 2006, 12, 363-372. [CrossRef] [PubMed]

77. Cheent, K.; Khakoo, S.I. Natural killer cells and hepatitis C: Action and reaction. Gut 2011, 60, $268-278$. [CrossRef]

78. Yoon, J.C.; Lim, J.B.; Park, J.H.; Lee, J.M. Cell-to-cell contact with hepatitis C virus-infected cells reduces functional capacity of natural killer cells. J. Virol. 2011, 85, 12557-12569. [CrossRef] 
79. Kim, H.; Bose, S.K.; Meyer, K.; Ray, R. Hepatitis C virus impairs natural killer cell-mediated augmentation of complement synthesis. J. Virol. 2014, 88, 2564-2571. [CrossRef] [PubMed]

80. Wen, C.; He, X.; Ma, H.; Hou, N.; Wei, C.; Song, T.; Zhang, Y.; Sun, L.; Ma, Q.; Zhong, H. Hepatitis C virus infection downregulates the ligands of the activating receptor, NKG2D. Cell. Mol. Immunol. 2008, 5, 475-478. [CrossRef]

81. Cosgrove, C.; Berger, C.T.; Kroy, D.C.; Cheney, P.C.; Ghebremichael, M.; Aneja, J.; Tomlinson, M.; Kim, A.Y.; Lauer, G.M.; Alter, G. Chronic HCV infection affects the NK cell phenotype in the blood more than in the liver. PLoS ONE 2014, 9, e105950. [CrossRef] [PubMed]

82. Sene, D.; Levasseur, F.; Abel, M.; Lambert, M.; Camous, X.; Hernandez, C.; Pene, V.; Rosenberg, A.R.; Jouvin-Marche, E.; Marche, P.N.; et al. Hepatitis C virus (HCV) evades NKG2D-dependent NK cell responses through NS5A-mediated imbalance of inflammatory cytokines. PLoS Pathog. 2010, 6, e1001184. [CrossRef] [PubMed]

83. Qing, X.; Koo, G.C.; Salmon, J.E. Complement regulates conventional DC-mediated NK-cell activation by inducing TGF-beta1 in Gr-1+ myeloid cells. Eur. J. Immunol. 2012, 42, 1723-1734. [CrossRef] [PubMed]

84. Qin, X.; Gao, B. The complement system in liver diseases. Cell. Mol. Immunol. 2006, 3, 333-340.

85. Ghebrehiwet, B.; Lim, B.L.; Kumar, R.; Feng, X.; Peerschke, E.I. gC1q-R/p33, a member of a new class of multifunctional and multicompartmental cellular proteins, is involved in inflammation and infection. Immunol. Rev. 2001, 180, 65-77. [CrossRef]

86. Sansonno, D.; Tucci, F.A.; Ghebrehiwet, B.; Lauletta, G.; Peerschke, E.I.; Conteduca, V.; Russi, S.; Gatti, P.; Sansonno, L.; Dammacco, F. Role of the receptor for the globular domain of C1q protein in the pathogenesis of hepatitis C virus-related cryoglobulin vascular damage. J. Immunol. 2009, 183, 6013-6020. [CrossRef]

87. Cummings, K.L.; Rosen, H.R.; Hahn, Y.S. Frequency of gC1qR+CD4+ T cells increases during acute hepatitis $\mathrm{C}$ virus infection and remains elevated in patients with chronic infection. Clin. Immunol. 2009, 132, 401-411. [CrossRef]

88. Ali, O.S.; Abo-Shadi, M.A.; Hammad, L.N. The biological significance of serum complements C3 and C4 in HCV-related chronic liver diseases and hepatocellular carcinoma. Egypt. J. Immunol. 2005, 12, 91-99.

89. Dumestre-Perard, C.; Ponard, D.; Drouet, C.; Leroy, V.; Zarski, J.P.; Dutertre, N.; Colomb, M.G. Complement C4 monitoring in the follow-up of chronic hepatitis C treatment. Clin. Exp. Immunol. 2002, 127, 131-136. [CrossRef]

90. Mazumdar, B.; Kim, H.; Meyer, K.; Bose, S.K.; Di Bisceglie, A.M.; Ray, R.B.; Ray, R. Hepatitis C virus proteins inhibit C3 complement production. J. Virol. 2012, 86, 2221-2228. [CrossRef]

91. Mazumdar, B.; Kim, H.; Meyer, K.; Bose, S.K.; Di Bisceglie, A.M.; Ray, R.B.; Diamond, M.S.; Atkinson, J.P.; Ray, R. Hepatitis C virus infection upregulates CD55 expression on the hepatocyte surface and promotes association with virus particles. J. Virol. 2013, 87, 7902-7910. [CrossRef]

92. Kim, H.; Meyer, K.; Di Bisceglie, A.M.; Ray, R. Inhibition of $\mathrm{c} 3$ convertase activity by hepatitis $\mathrm{C}$ virus as an additional lesion in the regulation of complement components. PLoS ONE 2014, 9, e101422. [CrossRef]

93. Brockman, M.A.; Knipe, D.M. Herpes simplex virus as a tool to define the role of complement in the immune response to peripheral infection. Vaccine 2008, 26 (Suppl. S8), I94-I99. [CrossRef] [PubMed]

94. Peng, Q.; Li, K.; Anderson, K.; Farrar, C.A.; Lu, B.; Smith, R.A.; Sacks, S.H.; Zhou, W. Local production and activation of complement up-regulates the allostimulatory function of dendritic cells through C3a-C3aR interaction. Blood 2008, 111, 2452-2461. [CrossRef]

95. Li, K.; Okemefuna, A.I.; Gor, J.; Hannan, J.P.; Asokan, R.; Holers, V.M.; Perkins, S.J. Solution structure of the complex formed between human complement C3d and full-length complement receptor type 2. J. Mol. Biol. 2008, 384, 137-150. [CrossRef] [PubMed]

96. Carroll, M.C. Complement and humoral immunity. Vaccine 2008, 26 (Suppl. S8), I28-I33. [CrossRef] [PubMed]

97. Kwon, Y.C.; Kim, H.; Meyer, K.; Di Bisceglie, A.M.; Ray, R. Distinct CD55 Isoform Synthesis and Inhibition of Complement-Dependent Cytolysis by Hepatitis C Virus. J. Immunol. 2016, 197, 1127-1136. [CrossRef] [PubMed]

98. Mikesch, J.H.; Buerger, H.; Simon, R.; Brandt, B. Decay-accelerating factor (CD55): A versatile acting molecule in human malignancies. Biochim. Biophys. Acta 2006, 1766, 42-52. [CrossRef] 
99. Ochoa, M.C.; Minute, L.; Rodriguez, I.; Garasa, S.; Perez-Ruiz, E.; Inoges, S.; Melero, I.; Berraondo, P. Antibody-dependent cell cytotoxicity: Immunotherapy strategies enhancing effector NK cells. Immunol. Cell. Biol. 2017, 95, 347-355. [CrossRef]

100. Sarobe, P.; Lasarte, J.J.; Zabaleta, A.; Arribillaga, L.; Arina, A.; Melero, I.; Borras-Cuesta, F.; Prieto, J. Hepatitis $C$ virus structural proteins impair dendritic cell maturation and inhibit in vivo induction of cellular immune responses. J. Virol. 2003, 77, 10862-10871. [CrossRef] [PubMed]

101. Kanto, T.; Hayashi, N.; Takehara, T.; Tatsumi, T.; Kuzushita, N.; Ito, A.; Sasaki, Y.; Kasahara, A.; Hori, M. Impaired allostimulatory capacity of peripheral blood dendritic cells recovered from hepatitis C virus-infected individuals. J. Immunol. 1999, 162, 5584-5591.

102. Zimmermann, M.; Flechsig, C.; La Monica, N.; Tripodi, M.; Adler, G.; Dikopoulos, N. Hepatitis C virus core protein impairs in vitro priming of specific $\mathrm{T}$ cell responses by dendritic cells and hepatocytes. J. Hepatol. 2008, 48, 51-60. [CrossRef]

103. Salou, M.; Franciszkiewicz, K.; Lantz, O. MAIT cells in infectious diseases. Curr. Opin. Immunol. 2017, 48, 7-14. [CrossRef] [PubMed]

104. Barathan, M.; Mohamed, R.; Vadivelu, J.; Chang, L.Y.; Saeidi, A.; Yong, Y.K.; Ravishankar Ram, M.; Gopal, K.; Velu, V.; Larsson, M.; et al. Peripheral loss of CD8(+) CD161(++) TCRValpha7.2(+) mucosal-associated invariant $\mathrm{T}$ cells in chronic hepatitis $\mathrm{C}$ virus-infected patients. Eur. J. Clin. Investig. 2016, 46, 170-180. [CrossRef] [PubMed]

105. Lukens, J.R.; Cruise, M.W.; Lassen, M.G.; Hahn, Y.S. Blockade of PD-1/B7-H1 interaction restores effector CD8+ T cell responses in a hepatitis C virus core murine model. J. Immunol. 2008, 180, 4875-4884. [CrossRef] [PubMed]

106. Golden-Mason, L.; Palmer, B.; Klarquist, J.; Mengshol, J.A.; Castelblanco, N.; Rosen, H.R. Upregulation of PD-1 expression on circulating and intrahepatic hepatitis $\mathrm{C}$ virus-specific CD8+ T cells associated with reversible immune dysfunction. J. Virol. 2007, 81, 9249-9258. [CrossRef] [PubMed]

107. Radziewicz, H.; Ibegbu, C.C.; Fernandez, M.L.; Workowski, K.A.; Obideen, K.; Wehbi, M.; Hanson, H.L.; Steinberg, J.P.; Masopust, D.; Wherry, E.J.; et al. Liver-infiltrating lymphocytes in chronic human hepatitis C virus infection display an exhausted phenotype with high levels of PD-1 and low levels of CD127 expression. J. Virol. 2007, 81, 2545-2553. [CrossRef] [PubMed]

108. Raziorrouh, B.; Ulsenheimer, A.; Schraut, W.; Heeg, M.; Kurktschiev, P.; Zachoval, R.; Jung, M.C.; Thimme, R.; Neumann-Haefelin, C.; Horster, S.; et al. Inhibitory molecules that regulate expansion and restoration of HCV-specific CD4+ T cells in patients with chronic infection. Gastroenterology 2011, 141, 1422-1431. [CrossRef] [PubMed]

109. Chen, J.H.; Perry, C.J.; Tsui, Y.C.; Staron, M.M.; Parish, I.A.; Dominguez, C.X.; Rosenberg, D.W.; Kaech, S.M. Prostaglandin E2 and programmed cell death 1 signaling coordinately impair CTL function and survival during chronic viral infection. Nat. Med. 2015, 21, 327-334. [CrossRef]

110. Kared, H.; Fabre, T.; Bedard, N.; Bruneau, J.; Shoukry, N.H. Galectin-9 and IL-21 mediate cross-regulation between Th17 and Treg cells during acute hepatitis C. PLoS Pathog. 2013, 9, e1003422. [CrossRef]

111. Ren, J.P.; Zhao, J.; Dai, J.; Griffin, J.W.; Wang, L.; Wu, X.Y.; Morrison, Z.D.; Li, G.Y.; El Gazzar, M.; Ning, S.B.; et al. Hepatitis $C$ virus-induced myeloid-derived suppressor cells regulate T-cell differentiation and function via the signal transducer and activator of transcription 3 pathway. Immunology 2016, 148, 377-386. [CrossRef] [PubMed]

112. Wu, C.G.; Budhu, A.; Chen, S.; Zhou, X.; Popescu, N.C.; Valerie, K.; Wang, X.W. Effect of hepatitis C virus core protein on the molecular profiling of human B lymphocytes. Mol. Med. 2006, 12, 47-53. [CrossRef] [PubMed]

113. Yao, Z.Q.; Prayther, D.; Trabue, C.; Dong, Z.P.; Moorman, J. Differential regulation of SOCS-1 signalling in B and T lymphocytes by hepatitis C virus core protein. Immunology 2008, 125, 197-207. [CrossRef] [PubMed]

114. Ceccherini-Silberstein, F.; Cento, V.; Di Maio, V.C.; Perno, C.F.; Craxi, A. Viral resistance in HCV infection. Curr. Opin. Virol. 2018, 32, 115-127. [CrossRef]

(C) 2019 by the authors. Licensee MDPI, Basel, Switzerland. This article is an open access article distributed under the terms and conditions of the Creative Commons Attribution (CC BY) license (http:/ / creativecommons.org/licenses/by/4.0/). 